\title{
Modern Vacation of Economic Development Indicators of Caspian Regions in Azerbaijan
}

\section{ZH Aliyev*}

Institute of Erosion and Irrigation of ANAS, Russia

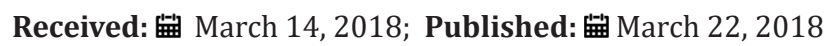

*Corresponding author: ZH Aliyev, Institute of Erosion and Irrigation of ANAS, Russia

\section{Economic Regions of Azerbaijan(Figure 1)}

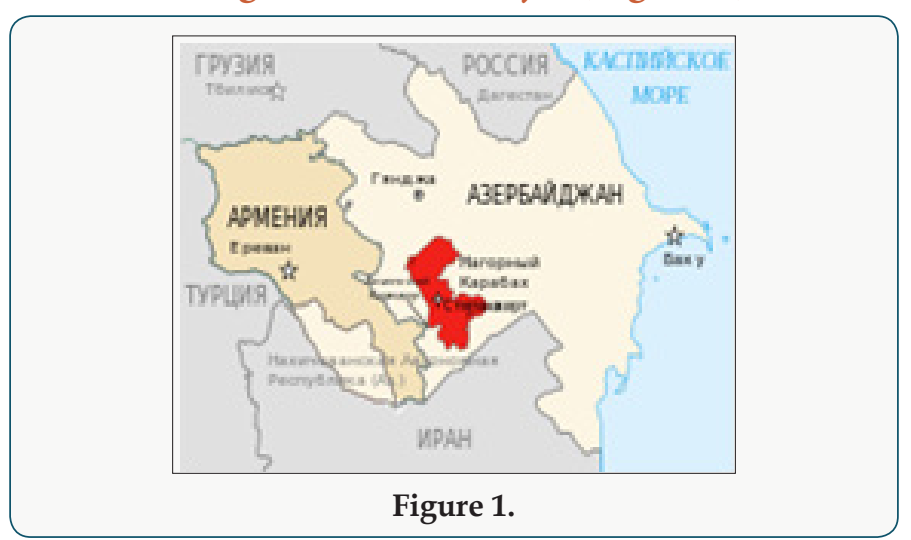

Absheron Economic Region

a. Area: 3,29 thousand $\mathrm{km}^{2}$.

b. Population: 551,800 people.

c. Administrative districts: Sumgait city, Absheron and Khizi districts.

d. Natural resources: sawdust, limestone, cements raw material, quartz, construction sand, balneological resources.

e. Main areas of the economy: Industrial and agrarianindustrial complex, tourism.

f. Industrial areas: oil and gas extraction, petrochemicals and chemistry, ferrous and non-ferrous metallurgy, energy, light and food industries.

g. Agrarian fields: livestock breeding, poultry farming, sheep breeding, vegetable growing, gardening, vine growing, flowering and dry subtropical fruits. Olive, saffron, pistachio and other products are grown.

h. Areas of service: Construction, transport, communic ation, tourism and so on. i. It is the only economic region with no domestic drinking water. The economic region is provided by drinking water and water pipes from the Samur and Kura rivers.

\section{Aran Economic Region}

a. Area: 21, 43 thousand $\mathrm{km} 2$.

b. Population: 1936,0 thousand people.

c. Administrative districts: Aghdash, Agjabadi, Barda, Beylagan, Bilasuvar, Goychay, Hajigabul, Imishli, Kurdamir, Neftchala, Saatli, Sabirabad, Salyan, Ujar, Zardab regions, Mingachevir, Yevlakh and Shirvan [1-8].

d. Natural resources: Oil, natural gas, iodine and bromine mineral water, building materials, solar energy, water resources, land suitable for cultivation.

e. Main areas of economy: Industry, agriculture.

f. Industrial areas: Electro-energy, chemical, mechanical engineering, light, food, construction materials. The power generated by two power plants in Mingachevir city is about 60 percent of the country's energy produced.

g. Agrarian areas: Cotton growing, grain growing, viticulture, dry subtropical fruit growing, horticulture. More than 90 percent of cotton produced in Azerbaijan is in this region. Potatoes and sugar beets are also grown in the region.

h. Areas of service: Transport, communication and so on.

\section{Daily Shirvan Economic Region}
a. Territory: 6,06,000 km2.
b. Administrative districts: Agsu, Ismayilli, Gobustan and Shamakhi districts. 
c. Population: 304,0 thousand people.

d. Natural resources: Stone, gravel, sand, lime, clay and construction materials, mineral waters.

e. Main Areas of Economy: Agriculture, Industry, Tourism and Folk Art.

f. Industrial areas: Food and light.

g. Agrarian Areas: Agriculture, Viticulture, Wine-Making and Livestock. The leading crop in agriculture is grain growing.

h. Areas of service: Transportation, tourism and so on.

\section{Ganja-Kazakh Economic Region}

a. Territory: $12,48 \mathrm{~km} 2$.

b. Population: 1240,8 thousand people.

c. Administrative districts: Agstafa, Dashkasan, Gadabay, Goranboy, Goygol, Gazakh, Samukh, Shamkir, Tovuz, Ganja and Naftalan.

d. Natural resources: iron ore, alunite, limestone, marble, gypsum, sealite, cement raw material, hydro-electric and natural-recreational resources.

e. Main Areas of Economy: Agriculture, Industry, Tourism and Folk Art.

f. Industrial areas: Heavy and Thinning: Black and nonferrous metallurgy, mechanical engineering, light industry, food industry and construction industry.

g. Agrarian areas: potato growing, viticulture, grain growing, horticulture, vegetable growing, fruits and livestock. About 13-14 percent of agricultural production in the Republic of Azerbaijan, including 80-85 percent of potatoes, 28 percent of grapes, and 15 percent of livestock products fall to this region.

h. Areas of service: Transportation, tourism, education, etc.

\section{Quba-Khachmaz Economic Region}

a. Area: $6,96 \mathrm{~km} 2$.

b. Population: 525.7 thousand people.

c. Administrative districts: Shabran, Khachmaz, Guba, Gusar and Siyazan districts.

d. Natural resources: Oil, natural gas, flammable shale, sand, gravel, clay, water resources, rich natural and recreational resources.

e. Main Areas of Economy: Agriculture, Industry, Tourism and Folk Art.

f. Industrial areas: Production, light, food. g. Agrarian fields: vegetable growing, fruits, grains, livestock.

h. Areas of service: Transportation, tourism and so on.

\section{Nakhchivan Economic Region}
a. Territory: 5.5 thousand $\mathrm{km} 2$.
b. Population: 439,800 people.
c. Administrative districts: Nakhchivan city, Sharur, Babek, Ordubad, Julfa, Shahbuz, Kangarli and Sadarak regions.

d. Natural resources: Molybdenum, polymetallic ores, stone, dolomite, marble, building materials and mineral water resources. All the molybdenum and dolomite reserves of the Republic of Azerbaijan and $60 \%$ of the mineral water resources fall to the Nakhchivan economic region. There are over two hundred mineral water reserves in the region.

e. Main areas of economics: industry, agriculture, service.

f. Industrial areas: Energy, electronics, cement, sugar, food, aluminum plates, furniture production, silkworm, carpet weaving and knitting.

g. Agrarian Areas: Tütuber production, viticulture, fruit growing, vegetable growing, gourds, sugar beet production, meat-milk and wool production, beekeeping and fishing. Service areas: Transport, tourism, science, education, etc.

\section{Lankaran Economic Region}
a. Territory: 6,07 thousand $\mathrm{km} 2$.
b. Population: 893,3 thousand.
c. Administrative districts: Astara, Jalilabad, Lerik, Masalli, Yardimli and Lankaran regions.

d. Natural resources: sawdust, river stone, sand, clay, gravel, thermalmineral waters. Seven of the 11 climatic zones in the world are found in the area of this economic region. $26 \%$ of the area is forest.

\section{e. Main Areas of Economy: Agrarian Industry, Tourism. \\ f. Industrial areas: Food, light, forest industry.}

g. Agrarian areas: flour vegetable growing, tea making, viticulture, grains citrus fishing, fishing, poultry, 99 percent of tea produced in the Republic of Azerbaijan, 27 percent of vegetables, 15 percent of grain, 24 percent of potatoes, 13 percent of grapes, 10 percent of fruit falls.

h. Areas of service: Transport, tourism, education and etc. 8.Kalbajar-Dachino economic region

i. Territory: 6,4 thousand $\mathrm{km} 2$.

j. Population: 244,000 persons. 
k. Administrative districts: Kalbajar, Lachin, Zangilan and Gubadli districts. All administrative regions included in the economic region are under Armenian occupation.

l. Natural resources: Gold, mercury, marble, facing stone, copal, perlite.

m. Main areas of economy: Agriculture, industry, tourism.

n. Industrial areas: Food and light.

o. Agrarian areas: Sheep and beef, beekeeping.

p. Areas of service: Transport, tourism 9. Shaki-Zagatala economic region.

q. Territory: 8,96 thousand $\mathrm{km} 2$.

r. Population: 599,9 thousand persons.

s. Administrative districts: Balakan, Gakh, Gabala, Oghuz, Zagatala and Sheki regions.

t. Natural resources: copper, sulfur arc, lead, zinc, gravel, sand, building materials, water resources. All of the copper reserves of the Republic of Azerbaijan account for 90 percent of the sulfur pellet, 97 percent of the lead, 99 percent of the zinc.

u. Main areas of economy: Agriculture, light and food industries, tourism.

v. Industrial areas: Light and food.

w. Agrarian areas: Tobacco, cereal, fruit growing, grain growing, vine-growing, meat-milk and meat-wool sheep breeding. More than 75 percent of tobacco produced in Azerbaijan, 17 percent of grain, 35 percent of barley, and 2 percent of green tea leaf fall on this economic region.

x. Service areas: Transport, tourism and etc. 10.Tomestic ward economic region.

y. Territory: $7.25 \mathrm{~km} 2$.

z. Population: 653.5 thousand.

a) Administrative districts: Agdam, Tartar, Khojavend, Khojali, Shusha, Jabrayil, Fuzuli and the city of Khankendi. Territories of Khojavand, Khojaly, Shusha, Jabrayil and Khankendi towns of the economic region are completely occupied by the Armenian occupation of Aghdam and Fuzuli regions.

b) Natural resources: Polymetal ore deposits, building materials, mineral waters. As Armenian occupants invaded other riches of the economic region, they destroyed valuable forest species in the forests and carried them to Armenia and plundered the unique forest fauna of the region.

c) Main areas of economy: Agriculture, industry and tourism. d) Industrial areas: Food and light.

e) Agrarian Areas: Viticulture, Grain-growing, Fruit-growing, Tobacco, Hunting, Beekeeping, Livestock.

f) Service Areas.

Transport, Tourism and Main Regional Development Programs

a. "State Program on Socio-Economic Development of the Regions of the Republic of Azerbaijan (2004-2008)" (11 February 2004).

b. “ (February 27, 2006).

c. "State Program on Socio-Economic Development of the Regions of the Republic of Azerbaijan in 2009-2013" (April 14, 2009).

d. "In 2011-2013, the city of Baku and its State program on socio-economic development of Baku and its suburbs in 20142016 (January 17, 2014).

e. "State Program on socio-economic development of settlements" (May 4, 2011) State Program on Socio-Economic DEVELOPMENT for Years "(February 27, 2014).

\section{Chlica Regional Development Programs}

More than 240 orders have been signed to accelerate the socioeconomic development of cities and regions in all economic regions during the implementation of both state programs on regional development.

\section{Main Results Of I And Li Regional Development Programs}

a. Development of the non-oil sector.

b. Increased business activity of the population.

c. Development of production infrastructure.

d. Improved utility services and social infrastructure.

e. Improvement of business environment.

f. Increased investment.

g. Creation of new enterprises and facilities producing competitive and export-oriented products meeting international requirements.

h. Reduced unemployment.

i. Reduction of poverty.

\section{Main Results Of I And Ii Regional Development Programs}

Between 2004 and 2014in 10 years: - GDP - 3.2 times, GDP per capita - 2.8 times, industry - 2.7 times, agriculture - 1.5 times, 
investments - 6.5 times, incomes - 6.5 times, non-oil the sector grew 2.6 times and the average annual economic growth in the country was $12.9 \%$. - Strategic currency reserves increased 31 times, foreign trade turnover - 6.6 times, exports - 9.3 times, imports - 4.1 times, non-oil exports - 4.7 times. - Revenues of the state budget increased 16 times, average monthly wages - 5.5 times, pensions 9.6 times, deposits of population - 27 times. - Domestic investments increased 14.6 times, investments in the non-oil sector increased by 12.9 times and 50.7 billion mantas were allocated to the regions through all sources.

\section{Main Results Of I And Ii Regional Development Programs}

10 years between 2004 and 2014: - More than 1.2 million new, including 900,000 permanent jobs, 55,600 new businesses were created. Nearly 80 percent of newly opened jobs fell to the regions. - In 2003 , only $26.8 \%$ of the total investment in the country's economy was funded from domestic sources; in 2013, the share of domestic investment reached $62.5 \%$. 35 five star hotels have been put into operation in 14 regions.

\section{Baku's Place In Azerbaijan Economy (2014)}

$53.4 \%$ of economic entities with legal status; $72.3 \%$ of product output; $87.8 \%$ of industrial production; $53 \%$ of retail trade turnover; $67.3 \%$ of funds directed to fixed capital; $45.6 \%$ of hired workers in the economy; $55.6 \%$ of the population's income.

\section{Main Objectives Of Regional Development Policy In The Years}

a. Development of the non-oil sector in the country.
b. Diversification of the economy.
c. Further improvement of infrastructure and social services related to rural development.

d. Accelerate the development of entrepreneurship in the direction of production of competitive and competitive products.

e. Increase the employment rate of the population, especially the rural population;

f. Poverty reduction.

\section{References}

1. Aras Osman Nuri, Suleymanov, Karim Mammadov (2016) Azerbaijan's Economy Baku: East-West.

2. Aras O N, Suleymanov, Mammadov K (2016) Economy of Azerbaijan Baku: Sharg-Garb.

3. Statistical indicators of Azerbaijan.

4. Bağırzade E (2011) XX of Independence Economics of the Republic of Azerbaijan. Hacettepe University Journal of Turkic Studies (15): 277312.

5. Baku (2004) State Program on Socio-Economic Development of the Regions of the Republic of Azerbaijan.

6. Baku (2009) State program of socio-economic development of the regions of the Republic of Azerbaijan in 2009-2013.

7. The socio-economic development of the regions of the Republic of Azerbaijan in the years 2014-2018. Economic Development State Program.

8. Speech of the President of the Republic of Azerbaijan.

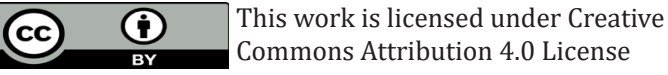

To Submit Your Article Click Here: Submit Article

DOI: $10.32474 /$ CIACR.2018.01.000119

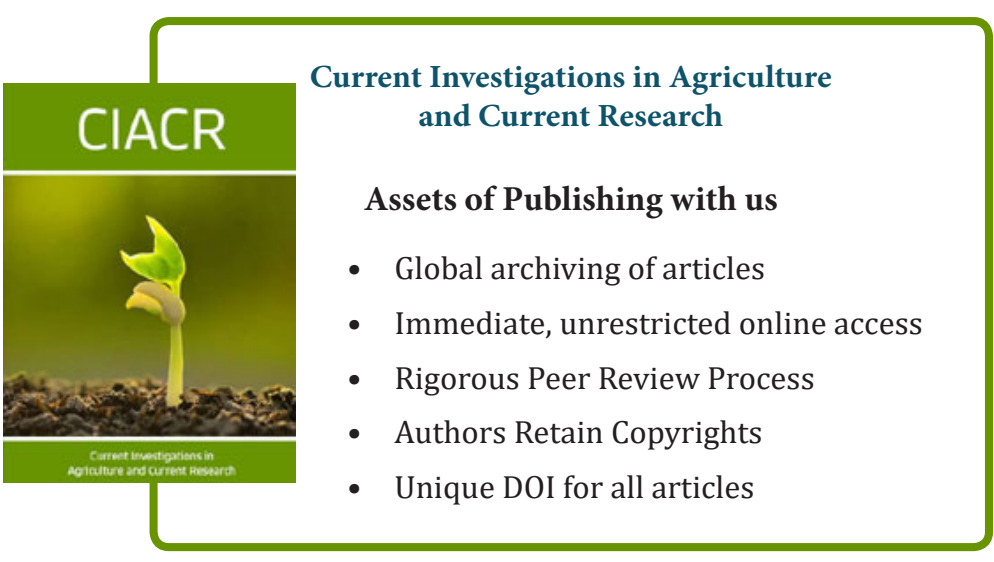

